\title{
Endoscopic banding without resection (BWR) technique for treatment of diminutive neuroendocrine tumors in the duodenum $\square$
}

\section{(ㄷ)(1) $(-2)$}

\author{
Authors
}

Harshit S. Khara ${ }^{1}$, Gerald J. Shovlin ${ }^{2}$, Amitpal S. Johal' ${ }^{1}$, David L. Diehl ${ }^{1}$

\author{
submitted 8.12.2016 \\ accepted after revision $\quad$ 17.4.2018 \\ Bibliography \\ DOI https://doi.org/10.1055/a-0684-9563 | \\ Endoscopy International Open 2019; 07: E302-E307 \\ (c) Georg Thieme Verlag KG Stuttgart · New York \\ ISSN 2364-3722
}

\section{Corresponding author}

Harshit S. Khara, MD, Center for Advanced Therapeutic Endoscopy, Department of Gastroenterology \& Nutrition, Geisinger Medical Center, 100 N. Academy Avenue, 21-11, Danville, PA 17822, USA

Fax: +1-570-271-6852

hskhara@geisinger.edu

\section{Introduction}

Duodenal neuroendocrine tumors (NETs) are rare malignancies accounting for $2-4 \%$ of gastrointestinal NETs, presenting as solitary small lesions confined to the duodenal submucosa [1]. Endoscopic ultrasound (EUS) is a valuable tool to assess the depth of mural involvement and check for lymph node metastasis. Although rare, there have been cases of local and distant metastases of diminutive (less than $10 \mathrm{~mm}$ ) duodenal NETs and thus endoscopic resection is recommended [1,2]. Endoscopic mucosal resection (EMR) and endoscopic submucosal dissection (ESD) of duodenal NETs are alternatives to surgical management, but carry a higher adverse event rate [3-6]. The application of an endoscopic band ligation technique, "banding

\begin{abstract}
Endoscopic treatment of diminutive (less than $10 \mathrm{~mm}$ ) duodenal neuroendocrine tumors (NETs) is recommended because of the risk of metastatic potential. Endoscopic mucosal resection and endoscopic submucosal dissection are alternatives to surgical management but have significant adverse event rates. We evaluated the effectiveness, feasibility, and safety of the 'banding without resection' (BWR) technique and assessed outcomes for the treatment of diminutive duodenal NETs. Our study included eight patients referred for endoscopic treatment of incidentally discovered, biopsy proven, diminutive duodenal bulb NETs. Endoscopic ultrasound (EUS) in all patients showed duodenal bulb NETs located in the deep mucosa and submucosal layers without any nodal metastasis. The BWR technique was successfully performed in all patients with technical feasibility, with the assistance of submucosal saline lift in three patients when the lesion was smaller than $5 \mathrm{~mm}$ in size, without any immediate or delayed adverse events. Complete resection with no residual lesion was confirmed at short-term (median 2.3 months) and long-term (median 4.2 years) follow-up intervals by repeat endoscopy, biopsy, and EUS exam. The BWR technique appears to be a safe, feasible, and effective therapy for endoscopic treatment of diminutive duodenal bulb NETs in the absence of local and distant metastasis.
\end{abstract}

without resection (BWR)", has been used for the management of mucosal lesions in the gastrointestinal tract with varying degree of success ranging from $75 \%$ to $100 \%$ [7 - 12]. We evaluated the effectiveness, feasibility, and safety of the BWR technique and assessed outcomes for treatment of diminutive NETs in the duodenal bulb, which has a higher potential for perforation or bleeding following resection due to the thin duodenal wall and increased vasculature. 


\section{Methods}

This is a retrospective analysis of a prospectively maintained case series database. Patients with a new diagnosis of diminutive duodenal bulb NET, without periduodenal lymph node metastasis, or prior endoscopic or surgical treatments were included from 2011 to 2016 at our tertiary care hospital. Institutional review board approval was obtained. Before the BWR procedure, the diagnosis of NET was confirmed by forceps biopsies using a large capacity biopsy forceps and utilizing the bite-onbite technique with an average of 2 passes with 4 bites, demonstrating NET with typical H\&E appearance and immunohistochemical staining for chromogranin and synaptophysin.

As per the 2012 ENETS Consensus Guidelines for the management of patients with gastroduodenal neoplasms [2], patients with diminutive duodenal NETs were offered the option of endoscopic resection, with choices of EMR, ESD, or BWR. The risks and benefits of each modality were explained, and patients who opted for BWR were enrolled in the study. The treatment indications for diminutive duodenal bulb NETs were explained to all of the patients and a written informed consent for endoscopic BWR was obtained.

EUS was performed with a radial echoendoscope (GFUE160-AL5, Olympus America, Center Valley, PA, USA) to assess NET size, wall layer(s) involved, and involvement of periduodenal lymph nodes. In three cases, where the lesion size was less than $5 \mathrm{~mm}$, a $20 \mathrm{MHz}$ EUS miniprobe (UM-G20-29R, Olympus America) was also used for better evaluation of the lesion margins. A forward-viewing gastroscope (GIF-H180 J, GIF-Q180, or GIF-HQ190 Endoscope, Olympus America) was fitted with a single bander device (Stiegmann-Goff Clearvue endoscopic ligator, ConMed Corp., Utica, NY, USA) which was used for the BWR technique. Submucosal saline lift using a 23-gauge injection therapy needle (Interject, Boston Scientific, Marlborough, MA, USA) before banding was carried out in three early cases where the lesion size was less than $5 \mathrm{~mm}$, for safer tissue capture on banding and to reduce the risk of full wall thickness capture due to small size of the lesion. The submucosal lesion was targeted in the middle of the cap, medium suction was applied to draw tissue into the cap, and the band deployed rapidly. No tattooing or marking of the BWR site was done, but its location in respect to the duodenal bulb was documented in detail with photographs and procedure report, for follow-up exam.

The patient was observed in the endoscopy unit on an outpatient basis post-procedure and was discharged home once stable. A post-procedure phone call was made to all patients at 24 hours to check for any post-procedure adverse events and a chart review was performed to check for any delayed procedure-related events or admissions. Repeat endoscopic evaluation was performed at an interval of 2 to 3 months after the BWR procedure for short interval follow-up; and then at least 2 years post-BWR for long interval follow-up for visualization and biopsy of the banded site. In some cases, a repeat EUS exam was done if there was any suspicion of a residual lesion on endoscopic exam, to confirm complete eradication for assessing the effectiveness and long-term outcomes of the BWR proce- dure, and also to rule out any delayed locoregional and lymph node metastasis.

\section{Results}

Nine patients meeting the initial endoscopic characteristics were evaluated, of which one case confirmed as a sub-centimeter NET on biopsy was excluded as EUS exam showed a positive metastatic periduodenal lymph node. Eight patients meeting all the study inclusion criteria underwent BWR therapy for duodenal bulb NETs ( $\triangleright$ Table 1 ). Seven of them were female, with a median age of 63 (range 34-79) years, undergoing endoscopy for abdominal pain, dysphagia, dyspepsia, reflux, and surveillance or treatment for Barrett's esophagus. The patient's median American Society of Anesthesiologists (ASA) class was 2.5 (range $2-3$ ). Endoscopy in these eight cases revealed an incidental finding of a diminutive deep mucosal $(n=2)$ or submucosal lesion $(n=6)$ often accompanied by a central depression and yellow color ( $\$$ Fig.1a), with biopsy confirming a NET

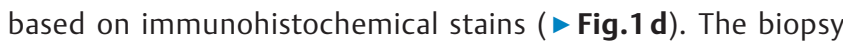
specimen from all eight patients showed a Ki-67 proliferative index of $<3 \%$, consistent with a low grade (G1), well differentiated duodenal NET, per the 2010 WHO classification [13]. Three of these patients underwent a CT scan and one patient had an octreoscan before BWR, which did not show any metastatic disease.

EUS exam done before BWR for local staging showed a welldefined hypoechoic lesion with median size of $6 \mathrm{~mm}$ (range 3$9 \mathrm{~mm})$, confined to the duodenal bulb deep mucosal $(n=2)$ or submucosal layers $(n=6)$. There were no suspicious lymph nodes on radial ( $>$ Fig. 1e) or miniprobe ( $>$ Fig. 1f) EUS evaluation. All lesions were stage I per the 2017 American Joint Committee on Cancer (AJCC) and the Union for International Cancer Control (UICC) neuroendocrine tumors of the duodenum and ampulla of Vater TNM staging; based on T1 (tumor invades the mucosa or submucosa only and is $\leq 1 \mathrm{~cm}$ ); N0 (no regional lymph node involvement); and M0 (no distant metastasis) [14]. Thus, no systemic therapy was needed.

For BWR therapy, three cases earlier in the series (size $<5 \mathrm{~mm}$ ) underwent a submucosal lift using saline/indigo carmine solution for safer tissue capture on banding and reducing the risk of full thickness capture due to small size of the lesion; while the later five cases (size $5-9 \mathrm{~mm}$ ) were performed without a lift. Successful banding of the NET was accomplished in all patients using the single bander device. After release of suction, the band could be seen at the neck of the lesion ( $\triangleright$ Fig.1b), with little or no additional tissue captured.

The procedure was feasible in all patients without any technical or clinical issues. All patients had an uneventful recovery and were discharged home on the day after the procedure done on an outpatient basis. There were no immediate or delayed adverse events related to the procedure in any of the patients.

All eight patients underwent repeat endoscopy for shortterm follow-up at a median of 2.3 months (range 62-94 days) after the BWR, showing a faint scar at the site of the therapy ( $\triangleright$ Fig.1c), without any endoscopic evidence of residual lesion. 
- Table 1 Case series summary.

\begin{tabular}{|c|c|c|c|c|c|c|c|c|c|c|c|}
\hline $\begin{array}{l}\text { Case } \\
\text { no. }\end{array}$ & $\begin{array}{l}\text { Age }(y) / \\
\text { Gender }\end{array}$ & $\begin{array}{l}\text { ASA } \\
\text { class }\end{array}$ & $\begin{array}{l}\text { Location } \\
\text { of NET } \\
\text { on EGD }\end{array}$ & $\begin{array}{l}\text { Size, } \\
\text { mm }\end{array}$ & $\begin{array}{l}\text { Ki-67 } \\
\text { index }\end{array}$ & Grade & $\begin{array}{l}\text { Differen- } \\
\text { tiation }\end{array}$ & $\begin{array}{l}\text { Depth } \\
\text { on EUS } \\
\text { exam }\end{array}$ & $\begin{array}{l}\text { Saline/ } \\
\text { indigo car- } \\
\text { mine lift }\end{array}$ & $\begin{array}{l}\text { Short term } \\
\text { follow-up, } \\
\text { mo }\end{array}$ & $\begin{array}{l}\text { Long term } \\
\text { follow-up, } \\
\text { mo }\end{array}$ \\
\hline 1 & $59 / F$ & 3 & $\begin{array}{l}\text { Duodenal } \\
\text { bulb }\end{array}$ & $3 \times 2$ & $<1 \%$ & $\begin{array}{l}\text { Low grade } \\
\text { (G1) }\end{array}$ & $\begin{array}{l}\text { Well differ- } \\
\text { entiated }\end{array}$ & $\begin{array}{l}\text { Submu- } \\
\text { cosa }\end{array}$ & $5 \mathrm{~mL}$ & 2.1 & $\begin{array}{l}\text { Patient } \\
\text { refused }\end{array}$ \\
\hline 2 & $34 / F$ & 3 & $\begin{array}{l}\text { Duodenal } \\
\text { bulb }\end{array}$ & $4 \times 3$ & $<3 \%$ & $\begin{array}{l}\text { Low grade } \\
\text { (G1) }\end{array}$ & $\begin{array}{l}\text { Well differ- } \\
\text { entiated }\end{array}$ & $\begin{array}{l}\text { Submu- } \\
\text { cosa }\end{array}$ & $5 \mathrm{~mL}$ & 2.3 & 67 \\
\hline 3 & $54 / F$ & 2 & $\begin{array}{l}\text { Duodenal } \\
\text { bulb }\end{array}$ & $4 \times 4$ & $2 \%$ & $\begin{array}{l}\text { Low grade } \\
\text { (G1) }\end{array}$ & $\begin{array}{l}\text { Well differ- } \\
\text { entiated }\end{array}$ & $\begin{array}{l}\text { Submu- } \\
\text { cosa }\end{array}$ & $2 \mathrm{~mL}$ & 2.1 & 40.2 \\
\hline 4 & $79 / F$ & 2 & $\begin{array}{l}\text { Duodenal } \\
\text { bulb }\end{array}$ & $6.5 \times 6$ & $<1 \%$ & $\begin{array}{l}\text { Low grade } \\
\text { (G1) }\end{array}$ & $\begin{array}{l}\text { Well differ- } \\
\text { entiated }\end{array}$ & $\begin{array}{l}\text { Deep } \\
\text { mucosa }\end{array}$ & None & 2.3 & 60.9 \\
\hline 5 & $62 / F$ & 2 & $\begin{array}{l}\text { Duodenal } \\
\text { bulb }\end{array}$ & $7 \times 5$ & $<1 \%$ & $\begin{array}{l}\text { Low grade } \\
\text { (G1) }\end{array}$ & $\begin{array}{l}\text { Well differ- } \\
\text { entiated }\end{array}$ & $\begin{array}{l}\text { Deep } \\
\text { mucosa }\end{array}$ & None & 2.2 & 55.9 \\
\hline 6 & $63 / \mathrm{M}$ & 2 & $\begin{array}{l}\text { Duodenal } \\
\text { bulb }\end{array}$ & $6 \times 5$ & $<1 \%$ & $\begin{array}{l}\text { Low grade } \\
\text { (G1) }\end{array}$ & $\begin{array}{l}\text { Well differ- } \\
\text { entiated }\end{array}$ & $\begin{array}{l}\text { Submu- } \\
\text { cosa }\end{array}$ & None & 3.1 & 47 \\
\hline 7 & $79 / F$ & 3 & $\begin{array}{l}\text { Duodenal } \\
\text { bulb }\end{array}$ & $9 \times 6$ & $<1 \%$ & $\begin{array}{l}\text { Low grade } \\
\text { (G1) }\end{array}$ & $\begin{array}{l}\text { Well differ- } \\
\text { entiated }\end{array}$ & $\begin{array}{l}\text { Submu- } \\
\text { cosa }\end{array}$ & None & 2.6 & $\begin{array}{l}\text { Patient } \\
\text { refused }\end{array}$ \\
\hline 8 & $77 / F$ & 3 & $\begin{array}{l}\text { Duodenal } \\
\text { bulb }\end{array}$ & $9 \times 5$ & $1 \%$ & $\begin{array}{l}\text { Low grade } \\
\text { (G1) }\end{array}$ & $\begin{array}{l}\text { Well differ- } \\
\text { entiated }\end{array}$ & $\begin{array}{l}\text { Submu- } \\
\text { cosa }\end{array}$ & None & 2.3 & 25.4 \\
\hline
\end{tabular}

ASA, American Society of Anesthesiologists; EGD, esophagogastroduodenoscopy; EUS, endoscopic ultrasound; NET, neuroendocrine tumor.
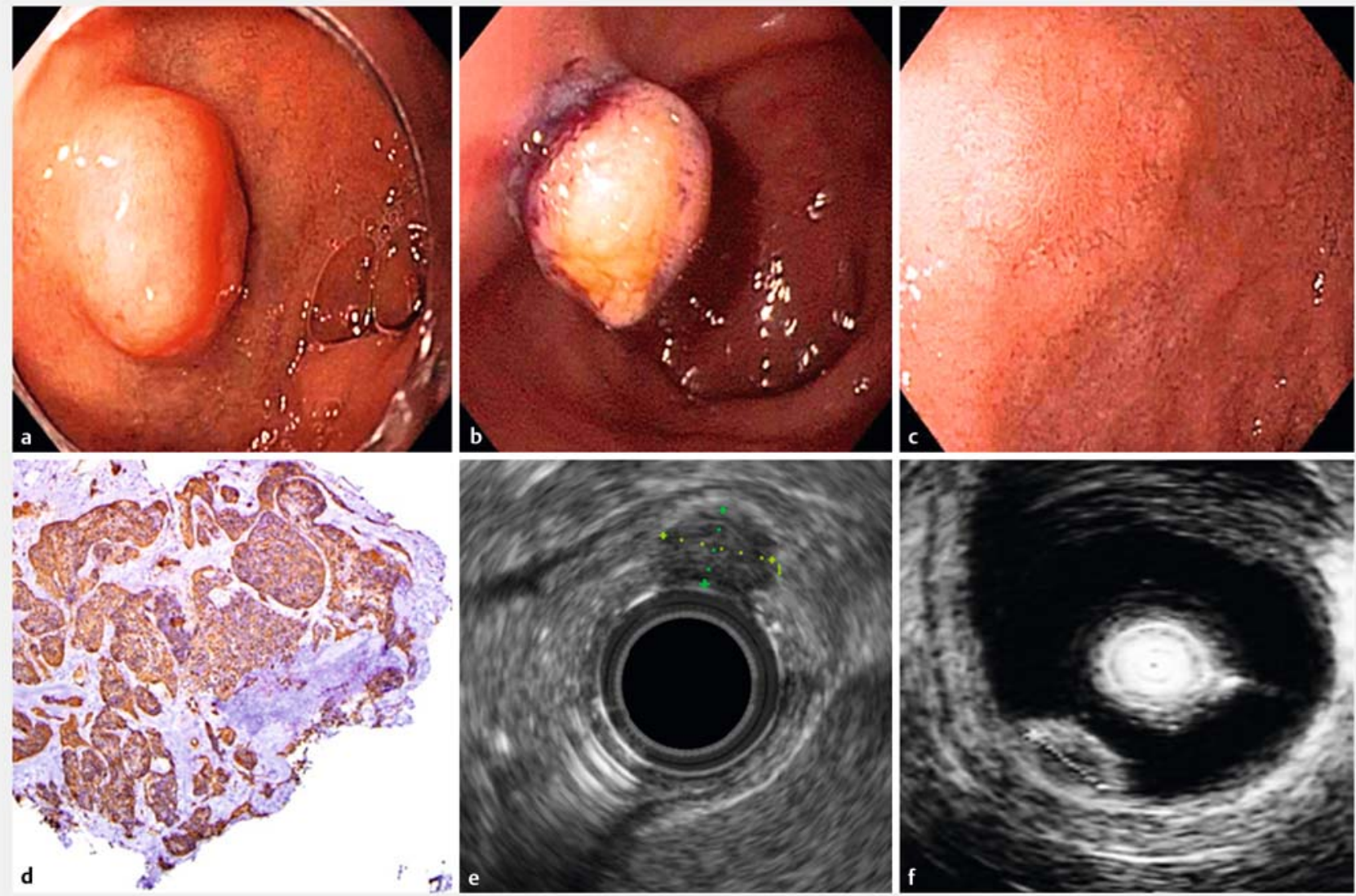

- Fig. 1 a Endoscopic appearance of a submucosal duodenal neuroendocrine tumor (NET); b subsequent endoscopic banding without resection (BWR) performed with the band at the neck of the lesion; $\mathbf{c}$ presence of a faint scar at the BWR site on follow-up. $\mathbf{d}$ Biopsy diagnosis of NET confirmed on chromogranin stain; endoscopic ultrasound (EUS) evaluation to assess the depth of the NET on radial (e) and miniprobe (f) exam and rule out periduodenal lymph node involvement. 
Post-BWR site biopsies performed in all eight patients did not reveal any microscopic evidence of residual NET. Radial EUS exam was done at the time of short-term follow-up in five patients because, although there was no gross lesion on endoscopic exam, there was some subtle nodularity at the site of the BWR scar. EUS exam in these patients confirmed no radiologic evidence of residual mucosal or submucosal lesion.

Six of these eight patients underwent repeat endoscopy 2 years or more later, at a median of 51.5 months (range 25.4 67 months) or 4.2 years (range 2.1 - 5.5 years), while two patients refused a long-term follow-up exam. There was no endoscopic evidence of any residual or recurrent NET in any of the six patients either by EUS examination or by post-BWR site biopsies at long-term follow-up.

Application of the BWR technique for treatment of diminutive neuroendocrine tumors in the duodenum is shown in - Video 1.

\section{Discussion}

Duodenal NETs are seen with decreasing frequency from the first to the third part of the duodenum [2], appearing as a deep mucosal or submucosal lesion on endoscopy, often with a yellow color ( $\mathbf{F i g . 1 b}$ ). Invasion of the muscularis propria, size greater than $2 \mathrm{~cm}$, and presence of mitotic figures have been identified as independent risk factors for metastasis of duodenal NETs, which could be as high as $21 \%$ [1]. Another study investigating duodenal NETs less than $10 \mathrm{~mm}$ in size showed a $14 \%$ rate of nodal metastasis which increased to $47 \%$ for tumors between 21 and $50 \mathrm{~mm}$ in size [15].

Current guidelines recommend that duodenal NETs less than $10 \mathrm{~mm}$ in size, without infiltration of the muscularis propria, and no associated hormonal syndrome, have a low metastatic potential, and should be treated by endoscopic techniques [2]. We have encountered a patient with a diminutive duodenal bulb NET with a rather large metastasis in a periduodenal lymph

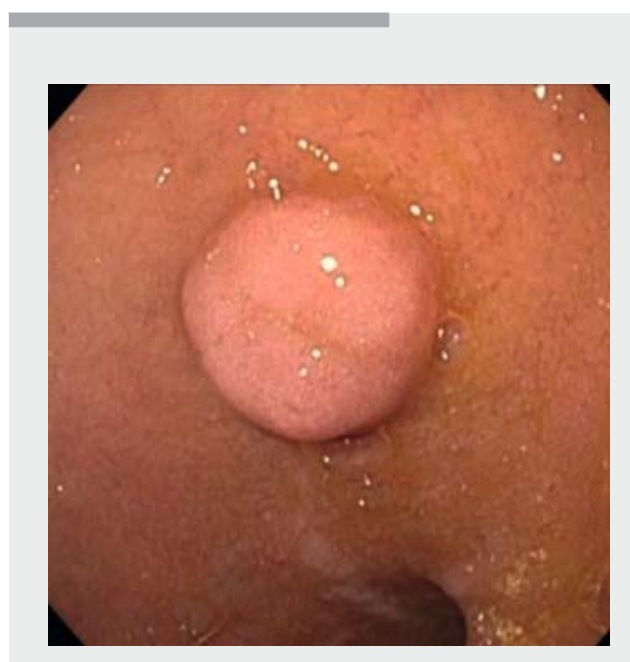

Video 1 Endoscopic banding without resection (BWR) technique for treatment of diminutive neuroendocrine tumors in the duodenum. node ( $>$ Fig. 2 a $-\mathbf{d}$ ) seen on EUS exam, who subsequently underwent surgical resection. Interestingly, the primary tumor was only $7 \mathrm{~mm}$ originating from the submucosa and abutting the muscularis propria, and the metastasis was $23 \mathrm{~mm}$ ! This case, excluded from our current study due to lack of lymph node clearance, presents a cautionary tale about the importance of careful EUS assessment for local nodal metastasis before considering endoscopic resection of diminutive duodenal NETs and highlights the fact that involvement of the muscularis propria is associated with an elevated risk of lymph node metastasis.

Since duodenal NETs are generally small (mean $1.2-1.5 \mathrm{~cm}$ ), with more than $75 \%$ of lesions less than $2 \mathrm{~cm}$ in size, they are frequently missed (>80\%) with conventional imaging studies such as multi-slice CT scan, MRI, ultrasound, or angiography. Somatostatin receptor scintigraphy (SRS) also provides a useful imaging modality for the detection of metastatic disease in patients with malignant NETs. Upper gastrointestinal endoscopy with biopsy and EUS is the most sensitive modality used to confirm the diagnosis and locally stage primary duodenal NETs [2]. Three of our patients underwent a CT scan and one patient had an octreoscan before BWR, which did not show any metastatic disease. However, all patients underwent upper endoscopy with biopsy and EUS exam before BWR.

Histologic confirmation followed by EUS exam to assess the depth of invasion and regional metastasis is imperative before deciding on a therapeutic strategy. In one series of 36 gastrointestinal NETs including 7 duodenal lesions, EUS accuracy was as high as $90 \%$ when limited to lesions detectable on EUS [16]. In our present study, none of the included patients had any associated clinical symptoms; all cases were detectable on EUS with size less than $10 \mathrm{~mm}$, and were confined to the deep mucosa or submucosa, without any evidence of periduodenal lymph node involvement. The use of the $20 \mathrm{MHz}$ EUS miniprobe in evaluation of lesions less than $5 \mathrm{~mm}$ in size was found to be very helpful to better delineate the wall layer involvement, in addition to the radial EUS exam. These smaller lesions (less than $5 \mathrm{~mm}$ ) also underwent a saline lift before the BWR technique in the hope of a better and safer capture as these were the initial cases in our experience. However, we now feel that this is not necessary and even these smaller lesions can be easily and safely removed with the BWR technique without the need for a submucosal saline lift.

Several endoscopic approaches have been reported for resection of duodenal NETs including EMR with or without band ligation and cap-assisted EMR, as well as ESD, an emerging technique requiring advanced technical expertise. However, both these modalities carry a significant risk of hemorrhage and perforation, with complication rates ranging from $18 \%$ to $40 \%$, and a mortality rate of up to $3 \%$ [3-6]. Despite these risks, the chances of incomplete resection (R1) can be as high as $44 \%$ on EMR and $20 \%$ on ESD cases [5,6]. These risks can be reduced by eliminating the use of electrosurgical resection, which can be accomplished with the use of the BWR technique. Despite the lack of electrosurgical current, BWR can also carry the risk of perforation even in the thick-walled stomach [17]. The BWR technique has been successfully reported for resec- 

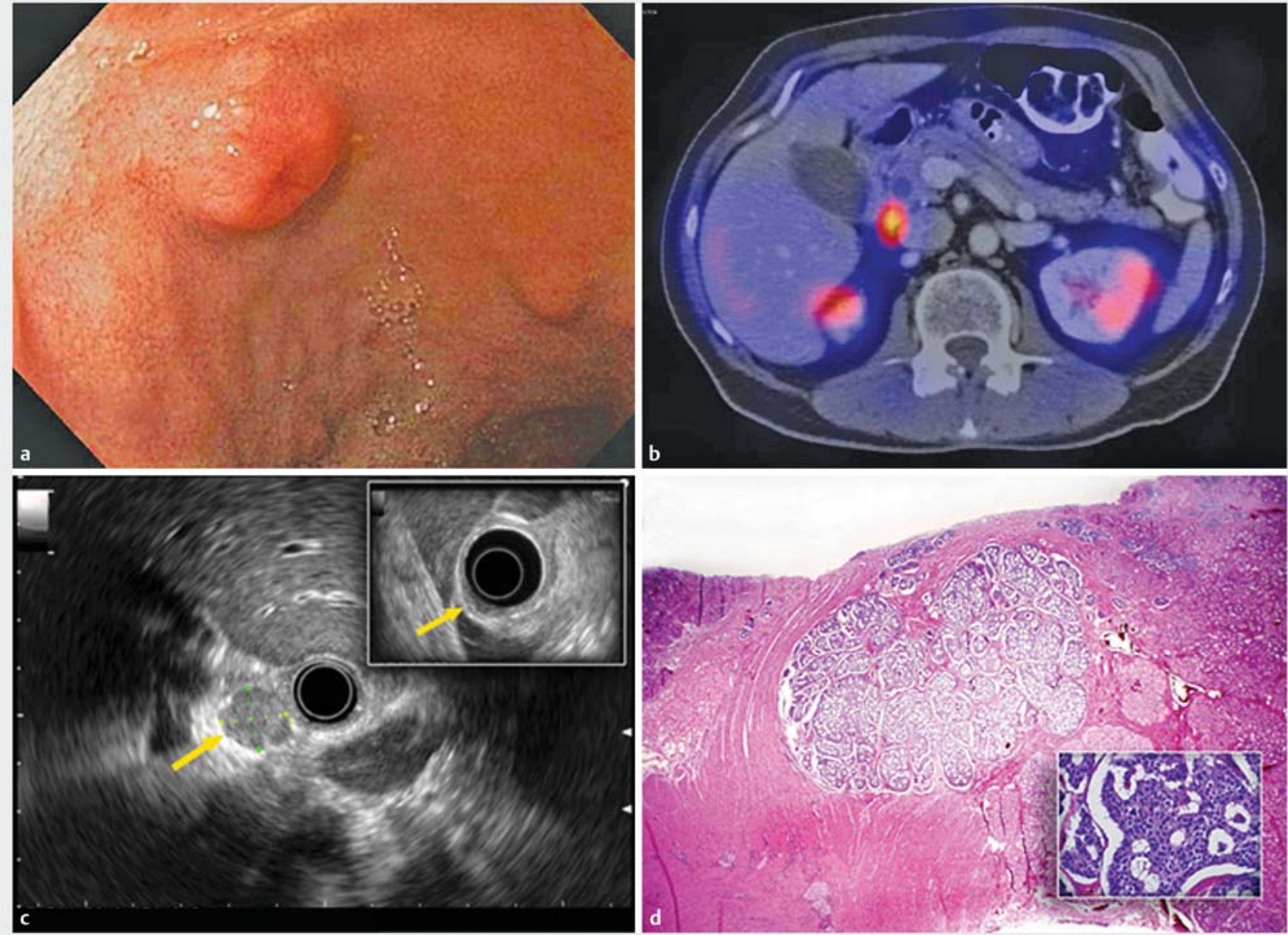

Fig. 2 The case of a diminutive duodenal NET with nodal metastasis, not treated with the BWR technique. a Endoscopic appearance; $\mathbf{b}$ enlarged periduodenal lymph node seen on Single-Photon Emission Computed Tomography (SPECT) imaging; $\mathbf{c}$ radial EUS exam showing the periduodenal lymph node and the barely visible primary duodenal lesion (inset, arrow). d Surgical pathology showing the primary NET arising from the submucosa extending to the muscularis propria ( $2 \times$ magnification) with typical nests of neuroendocrine cells (inset, $40 \times$ ).

tion of short-segment Barrett's esophagus, esophageal squamous carcinoma and adenocarcinoma, gastric high grade dysplasia, gastric and duodenal stromal tumors, gastric and duodenal NETs, duodenal gastrinoma, and upper gastrointestinal leiomyoma with varying degrees of success ranging from $75 \%$ to $100 \%$ (summarized in $>$ Table 2 ) $[7-12,17]$.

We evaluated the performance of the BWR technique for the treatment of diminutive NETs in the duodenal bulb. All cases in this series were clinically and procedurally successful and showed complete eradication of the NET using the BWR technique. There were no immediate or delayed adverse events related to the procedure and specifically, no cases of perforation or bleeding were encountered. A potential limitation of this technique is the inability to assess the deep margin of the resection and obtain a final pathological examination to assess for resection type (R0/R1). This raises the concern for residual neuroendocrine cells once the banded NET necroses and sloughs away with the risk of recurrence. However, subsequent endoscopy, biopsies, and EUS evaluation of the banded site, in all eight patients at short-term follow-up, and the available six patients with up to 5.5 years of long-term follow-up, did not show any evidence of residual or recurrent NET, which is reassuring for complete resection of these small lesions. We understand that our study represents a retrospective single center case series experience, but given our reassuring long-term follow-up data, we feel that the BWR technique appears to be a safe, feasible, and effective procedure for endoscopic resection of diminutive NETs in the absence of local or distant metastases. 
- Table2 Literature review of previously reported BWR cases.

\begin{tabular}{|c|c|c|c|c|c|}
\hline $\begin{array}{l}\text { Authors, year } \\
\text { [reference] }\end{array}$ & $\begin{array}{l}\text { Number of } \\
\text { patients }\end{array}$ & Type of lesion & $\begin{array}{l}\text { Mean follow- } \\
\text { up interval }\end{array}$ & $\begin{array}{l}\text { Success } \\
\text { rate }\end{array}$ & Adverse events \\
\hline $\begin{array}{l}\text { Diaz-Cervantes et } \\
\text { al., } 2007 \text { [7] }\end{array}$ & 30 & $\begin{array}{l}\text { Short segment Barrett's } \\
\text { esophagus }\end{array}$ & 16.9 months & $97 \%$ & No major adverse events \\
\hline Sun et al., 2007 [8] & 29 & $\begin{array}{l}\text { Gastric stromal tumors } \\
<12 \mathrm{~mm} \text { in size }\end{array}$ & 41 months & $96 \%$ & $\begin{array}{l}\text { Bleeding in one patient con- } \\
\text { trolled with endoscopic therapy }\end{array}$ \\
\hline Sun et al., 2009 [9] & 19 & $\begin{array}{l}\text { Duodenal stromal tumors } \\
<12 \mathrm{~mm} \text { in size }\end{array}$ & 47.7 months & $100 \%$ & $\begin{array}{l}\text { Self-limited bleeding in two pa- } \\
\text { tients, not requiring therapy }\end{array}$ \\
\hline Lee et al., 2009 [10] & 1 & $\begin{array}{l}\text { Duodenal gastrinoma } 8 \mathrm{~mm} \\
\text { in size }\end{array}$ & 8 weeks & $100 \%$ & No major adverse events \\
\hline Sun et al., 2004 [11] & 59 & $\begin{array}{l}\text { Upper gastrointestinal leio- } \\
\text { myoma }<15 \mathrm{~mm} \text { in size }\end{array}$ & 22 months & $95 \%$ & No major adverse events \\
\hline $\begin{array}{l}\text { Ibáñez-Sanz et al., } \\
2016 \text { [12] }\end{array}$ & 12 & $\begin{array}{l}\text { Esophageal squamous carci- } \\
\text { noma and adenocarcinoma; } \\
\text { gastric high grade dysplasia, } \\
\text { adenocarcinoma, and NETs; } \\
\text { duodenal NETs }\end{array}$ & 30.6 months & $\begin{array}{l}100 \% \\
\text { endoscopic } \\
\text { and } 75 \% \\
\text { histologic }\end{array}$ & No major adverse events \\
\hline Siyu et al., 2010 [17] & 2 & $\begin{array}{l}\text { Gastric stromal tumors } \\
<5 \mathrm{~mm} \text { in size }\end{array}$ & $24-35$ hours & NA & $\begin{array}{l}\text { Perforations in both cases requir- } \\
\text { ing surgical repair }\end{array}$ \\
\hline
\end{tabular}

\section{Competing interests}

None

\section{References}

[1] Burke AP, Sobin LH, Federspiel BH et al. Carcinoid tumors of the duodenum. A clinicopathologic study of 99 cases. Arch Pathol Lab Med 1990; 114: 700 - 704

[2] Delle Fave G, Kwekkeboom DJ, Van Cutsem E et al. ENETS Consensus Guidelines for the management of patients with gastroduodenal neoplasms. Neuroendocrinology 2012; 95: 74-87

[3] Ahmad NA, Kochman ML, Long WB et al. Efficacy, safety, and clinical outcomes of endoscopic mucosal resection: a study of 101 cases. Gastrointest Endosc 2002; 55: 390 - 396

[4] Min BH, Kim ER, Lee JH et al. Management strategy for small duodenal carcinoid tumors: does conservative management with close followup represent an alternative to endoscopic treatment? Digestion 2013; 87: 247-253

[5] Gincul R, Ponchon T, Napoleon B et al. Endoscopic treatment of sporadic small duodenal and ampullary neuroendocrine tumors. Endoscopy 2016; 48: 979-986

[6] Matsumoto S, Miyatani H, Yoshida Y et al. Duodenal carcinoid tumors: 5 cases treated by endoscopic submucosal dissection. Gastrointest Endosc 2011; 74: $1152-1156$

[7] Diaz-Cervantes E, De-la-Torre-Bravo A, Spechler SJ et al. Banding without resection (endoscopic mucosal ligation) as a novel approach for the ablation of short-segment Barrett's epithelium: results of a pilot study. Am J Gastroenterol 2007; 102: 1640-1645
[8] Sun S, Ge N, Wang C et al. Endoscopic band ligation of small gastric stromal tumors and follow-up by endoscopic ultrasonography. Surg Endosc 2007; 21: $574-578$

[9] Sun S, Ge N, Wang S et al. EUS-assisted band ligation of small duodenal stromal tumors and follow-up by EUS. Gastrointest Endosc 2009; 69: $492-496$

[10] Lee SH, Hong YS, Lee JM et al. Duodenal gastrinoma treated with endoscopic band ligation. Gastrointest Endosc 2009; 69: 964-967

[11] Sun S, Jin Y, Chang G et al. Endoscopic band ligation without electrosurgery: a new technique for excision of small upper-Gl leiomyoma. Gastrointest Endosc 2004; 60: 218-222

[12] Ibáñez-Sanz G, Gornals JB, Rivas L et al. Endoscopic band ligation without resection in selected patients for small and superficial upper gastrointestinal tract lesions. Rev Esp Enferm Dig 2016; 108: 250 256

[13] Rindi G, Arnold R, Bosman FT et al. Nomenclature and classification of neuroendocrine neoplasms of the digestive system. In: Bosman TF, Carneiro F, Hruban RH et al., eds. WHO classification of tumours of the digestive system. 4th edn. Lyon: International Agency for Research on cancer (IARC); 2010: 13

[14] Gress DM, Edge SB, Gershenwald JE et al. Principles of cancer staging. In: Amin MB, Edge SB, Greene FL et al., eds. AJCC cancer staging manual. 8th edn. New York: Springer; 2017: 3-30

[15] Soga J. Endocrinocarcinomas (carcinoids and their variants) of the duodenum. An evaluation of 927 cases. J Exp Clin Cancer Res 2003; 22: $349-363$

[16] Yoshikane H, Tsukamoto Y, Niwa Y et al. Carcinoid tumors of the gastrointestinal tract: evaluation with endoscopic ultrasonography. Gastrointest Endosc 1993; 39: 375 - 383

[17] Siyu S, Sheng W, Guoxin W et al. Gastric perforations after ligation of $\mathrm{Gl}$ stromal tumors in the gastric fundus. Gastrointest Endosc 2010; 72: $615-616$ 